\title{
Must Psychoanalysis be Scientific?
}

\author{
J. R. KING, Senior Registrar and Honorary Lecturer in Psychiatry, Middlesex Hospital, London W I
}

In spite of the vast strides forward made by the brain sciences this century, the gap between our understanding of the brain and our understanding of the mind remains uncomfortably wide. At one end of the scale, physical scientists scratch patiently away at the chemistry of receptor sites on cell membranes, at the other, clinicians make brilliant deductions by sheer intuition, and in between is a hazy land. As the pendulum now swings back towards a biological approach to psychiatry, we hear again the old assertion that the only true knowledge can be obtained by objective observation; subjective intuition must therefore be suspect, an unreliable and intangible entity. What validity is there in this argument?

Consider the introductory words of a standard and influential British textbook of psychiatry: 'This book is based on the conviction that the foundations of psychiatry have to be laid on the ground of the natural sciences'.' This could imply that peoples' real human sorrows and sufferings, angers and justified resentments, griefs and lonelinesses, can in effect be reduced to neurophysiology and biochemistry. Critics of such an approach have compared it to that of the surgeons who dissected Beethoven's brain after his death in order to find his genius.

It must be added, in fairness, that in their writings MayerGross, Slater and Roth do not pursue their stated conviction in such an extreme way, but adopt a more pragmatic and empirical approach. In fact, the practical and 'common sense' approach of British psychiatry is highly regarded, and rightly so. It should also be noted that the German school of psychiatry, as expounded by Fish, specifically rejects reductionism. Perhaps the modern scientific reductionists are more to be found in the ranks of the 'physiological psychologists'. These workers can become enmeshed in all kinds of difficulties when interpreting their results. For example, they may claim that states such as anger can be studied by measuring skin conductivity. Are they measuring anger itself or the responses produced by anger? They assume that for the purposes of study anger must be equated with its behavioural manifestations. Accepting this for the moment, how do they know that the subject is really feeling angry when these responses occur? The only way is because the subject says so. But this is a totally subjective impression (of the person being tested) and therefore invalid by their own criteria.

The physiological psychologists' reply to this sort of criticism is that they are not studying emotional disturbance, they are studying abnormal behaviour. But this is a different matter altogether. The difference between these two might be compared to the difference between the explosion of a stick of gelignite and a person who explodes with anger. The former is a bang, it can be measured in decibels; the latter is experienced directly-the angry person radiates an emotionally charged atmosphere and the observer knows what he is feeling because he too has felt like that. As Hutter put it: '[In psychodynamics] we describe all happenings in terms of psychical reality, so we can dispense with that framework of physical space-time which does not apply to mental phenomena.' H. V. Dicks put it even more succinctly: 'While behaviour is subject to scientific observation of an objective kind, experience is not-it needs to be shared and understood.'

Having agreed that science cannot be totally impersonal, and having agreed that 'objective impersonality' is to some extent an absurd and self-contradictory aim in a subject like psychiatry which is concerned with persons as subjects, we can now consider what progress has been made by investigators who favour the subjective approach. At once we come across a fresh difficulty of no two psychiatrists agreeing on a diagnosis. If psychiatrists $A$ and $B$ have incompatible opinions about patient $\mathrm{C}$, is one right and the other wrong? Or are both right in sense of expressing their true feelings about patient $C$ ? In this case, is the discrepancy due to difference in the psychiatrists' perceptions of patient $\mathrm{C}$, or is it due to the different behaviour of patient $C$ towards psychiatrists $\mathbf{A}$ and $\mathbf{B}$ ?

Psychodynamic approaches abound with divergences and contradictions of this sort, to a greater extent than organic psychiatry. There are so many 'dynamic' therapies, ranging from relatively coherent classical psychoanalytical theories, through existentialism, client-centred therapy and transactional analysis, to the encounter movement and primal scream therapy and a hundred other types of therapy in the United States, some of them tending towards the bizarre. An analogous situation existed in medicine when there were few effective drug treatments; the lack was met by a profusion of quack remedies, all claiming to be panaceas and all equally ineffective.

Another reason why dynamic psychiatry has come in for discredit is the presence in it of extremist groups. I am thinking, for example, of the gurus of the anti-psychiatry movement with their near paranoid outlook and vaguely subversive appeal, who have allowed their potentially creative thinking to become distorted by unresolved personal difficulties. We come here to the crux of the problem in the subjective approach, namely the ever-present danger of the therapist reading his own difficulties into those presented by the patient, of dimly perceiving idiosyncrasies in his own make-up and then putting them forward as general psychological theories of universal validity.

No one was more aware of such pitfalls than Freud, 
whose 'science' of psychoanalysis paid special attention to the need to disentangle inner perceptions from outer reality by means of the personal analysis, mandatory for the training of every intending psychoanalyst. Freud's unique capacity for insight and his powerful style of writing won him a widespread impact on modern thought. Yet opposition to psychoanalysis has never ceased and is currently stronger than ever. Early accusations about 'reducing everything to sex' have given way to modern objections about it being 'unscientific'.

What is the origin of this hostility towards psychoanalysis? To begin with, Freud's discoveries were not flattering to man's ego. They were the last straw in a series of scientific advances which put mankind in his place in the universe, and that place was a humble one. Before Galileo man had been at the centre of the universe with the sun rotating around him. Galileo was not popular when he showed that the reverse was the case. Before Darwin, man had been assured of his place in creation, far above the other animals. The Church did not like it when such an idea was challenged. But even after Darwin had shaken a few sacred beliefs, man could still regard himself as a rational being who was fully aware of his own mind. Until Freud began to shatter this last illusion, suggesting that man is not master in his own house, that his thoughts and actions are often influenced by feelings of which he is unaware.

Opposition to Freud's work has come from both outside and inside the psychoanalytic movement. From outside it has sometimes been attacked, more often ignored. Within the movement itself, it shows itself in a subtler form, a splitting off of splinter groups who were unable to tolerate some aspect of Freud's thought, and broke away to found schools of their own. A prime example was Jung, whose quarrel with Freud is documented in their correspondence. ${ }^{2}$ Jung's conception of psychoanalysis, with its rather mystical quality, has appealed to thinkers of a religious temperament. Indeed, the whole area of psychoanalysis has strong links with theology, many psychotherapists having a theological background. ${ }^{3}$ The unfortunate aspect of this is the division of psychoanalysis into rival schools, analogous to religious sects, whose disciples believe they alone have a true understanding of the significance of Freud's work.

In Britain, the influential work of Melanie Klein ${ }^{4}$ was a classic example of this phenomenon. For years a tremendous struggle raged in the British Psycho-Analytical Society between the followers of Klein and the more orthodox analysts who regarded her work as heresy. Melanie Klein pushed the understanding of the child's mind back to the early months of life. She postulated the existence of a 'depressive position' and a more primitive 'paranoid schizoid position' which had their counterparts in the major mental illnesses of later life: depression and schizophrenia.

An interesting criticism of Klein's work is that by paying so much attention to inner mental processes, it ignored the influence of the external environment. ${ }^{5}$ Whereas Freudians tended to see the baby as the innocent victim of maternal rejection, Kleinians viewed the infant as innately full of the most savage impulses which were the source of its own undoing. Apart from the religious implications of this (the doctrine of original sin), it also reflects the familiar hereditary $v$ environment controversy which has traditionally pervaded the more classically scientific areas of psychiatric research.

But perhaps what psychoanalytic thought brings especially to the advancement of knowledge, which traditional science tends to ignore, is the full personal involvement of the mind of the investigator, with all its personal problems and unresolved difficulties included. One of the most committed psychoanalytic pioneers in recent times was Dr Harry Guntrip, an ex-minister of the church turned psychotherapist, whose mission in life was to reformulate psychoanalysis in terms of an object relations (personal relations) theory. ${ }^{6}$ A powerful writer of popular self-help books and learned tomes in the International Psycho-Analytical Library, he staunchly maintained that Freud had been held back by the old-fashioned conceptions of science which had dominated the thinking of his day. Thus, although Freud's intuitive genius had leapt ahead to new insights, his theory had remained chained down to old mechanistic concepts such as id, ego, and super-ego, as these had formed his educational inheritance. The interesting feature which has since come to light ${ }^{7}$ was that this slavish adherence to older ways of thinking was Guntrip's problem even more than Freud's. Guntrip had remained dominated by his own ageing analyst until almost the end of his life, constantly feeling resentment against the analyst's formality and lack of warmth, constantly frustrated by the same overintellectual interpretations, but impelled by an obligation to champion his analyst's work at the expense of Guntrip's own creative insights. ${ }^{8,9}$

Just occasionally, such personal experiences can have a more general validity, and perhaps this is one such case. It is certainly a strange paradox in the history of science that the greater the merits of a way of thinking, the greater will be its effects in retarding subsequent developments. Einstein maintained, for example, that Aristotle's ideas of motion retarded the development of modern mechanics by two thousand years. It is quite probable that psychoanalysis is being held back in the same way, by invidious comparisons with the natural sciences, whereas it needs to be seen as a separate, though complementary, approach.

REFERENCES

'MAYer-Gross, W., Slater, E. \& Roth, M. (1969) Clinical Psychiatry. London: Baillière Tindall.

${ }^{2}$ McGuire, W. (ed) (1974) The Freud-Jung Letters. London: Hogarth Press and Routledge and Paul.

${ }^{3}$ Clare, A. \& Thompson, S. (1981) Let's Talk About Me. BBC Publications.

'SEgAL, H. (1964) Introduction to the Work of Melanie Klein (eds. M. Masud and R. Khan). International Psycho-Analytical Library, No. 91. 
'Guntrip, H. J. S. (1971) Psychoanalytic Theory, Therapy and the Self. London: Hogarth Press; New York: Basic Books.

6 _ (1968) Schizoid Phenomena, Object Relations and the Self. London: Hogarth Press; International Psycho-Analytical Library, No. 77.

7 (1975) My experiences of analysis with Fairbairn and Winnicott. International Review of Psycho-Analysis, 2, 145.
${ }^{8}$ Glatzer, H. T. \& Evans, W. N. (1977) On Guntrip's analysis with Fairbairn and Winnicott. International Journal of Psychoanalytic Psychotherapy, 6, 81-98.

'ElGEN, M. (1981) Guntrip's analysis with Fairbairn and Winnicott: A critique of Glatzer and Evans. Contemporary PsychoAnalysis, 17, No. 1.

\title{
Educational Programmes for General Practitioners and Clinical Assistants in the Mental Handicap Service
}

\author{
Joan Bicknell, Professor of the Psychiatry of Mental Handicap, St George's Hospital, London SW 17
}

The current trend towards community care for mentally handicapped people means that general practitioners have greater opportunities to meet mentally and multiply handicapped people living in the family home or in small units in the community. In addition, an increasing number of large long-stay mental handicap hospitals have delegated the reponsibility for primary care to local GPs, frequently employed as clinical assistants for this purpose. This is having the welcome effect of allowing the psychiatrist and the trainee in psychiatry to follow their particular interests and develop their own treatment skills.

The success of such a primary care service depends on local interest from GPs, their job description and the level of support available to them from the multidisciplinary team, including the psychiatrist and the hospital administrator. For some the role is still seen to be small and is restricted to somatic care with no involvement in the multidisciplinary discussions. Others only cover the service outside normal working hours. An increasing number of GPs are being given a wider remit, and yet some may not feel that they have the training, the skills, or day-to-day contact with other team members to offer a full primary care service to this patient group.

To remedy this situation in one London Borough, train ing for four GPs in the Mental Handicap Service began in 1979, with six evenings devoted to the following topics: aetiology of mental handicap; epidemiology and prevention and mental handicap; patterns of care; additional handicaps; psychiatric illnesses and behaviour disorders; and treatment techniques.

Enthusiasm for this initial course resulted in monthly meetings for all doctors in the service, i.e. GPs, psychiatrists and visiting consultants, together with the chiropodist, audiometrician and pharmacist, where they learned more of each other's roles. A recent variation has been to hold psychopharmacology seminars where case histories spreading over many years have been presented with particular reference to diagnosis and the uses and abuses of medication, drug interactions and side effects. This programme was then complemented by two monthly educational visits when some of these doctors would visit another service and together appraise their findings.

Despite many shortcomings, this programme resulted in a cohesive group of GPs who together have been able to provide a total primary care service, including basic psychiatry and preventive medicine, with a 24-hour emergency service for a 200-bed hospital. In one community unit, the GP has extended his role to primary care adviser to the Community Mental Handicap Team and has been a valuable link with local GPs.

The result of working, learning and visiting together has been a rise in standard of primary care and psychiatry for mentally handicapped people in the long-stay hospital, in community units, in hostels and their own homes within the catchment area served.

Arising from the enthusiasm for this range of learning opportunities, being aware of the current trends in the provision of community care and conscious of the improvements in the service already witnessed, an experimental twoday residential course was set up in November 1983 by the Regional Adviser in General Practice, Dr Trevor Silver, and myself as the Regional Postgraduate Tutor in Mental Handicap.

The course was advertised through the auspices of the British Postgraduate Medical Federation, throughout the four Metropolitan Regional Health Authorities for GPs and clinical assistants involved or interested in the services for mentally handicapped people.

Thirty GPs and clinical assistants attended the course, including some GP trainees and their trainers. There were 12 people from several disciplines participating in the teaching, all associated with the Section of Psychiatry of Mental Handicap, St George's Hospital Medical School. The course started with brief introductions, a resume of each person's professional and personal contact with mental handicap and what he or she wanted from the course. A variety of teaching methods were used.

Didactic lectures: these covered the history of care of mentally handicapped people, organization of services at present and plans for the future; the causes and prevention of 